\title{
João do Rio in Portugal: Counterfeit Currency and Luso- Brazilian Desleixo
}

\author{
ROBERT PATRICK NEWCOMB
}

University of California, Davis

\begin{abstract}
In this article, I examine an anecdote concerning a counterfeit coin included in João do Rio's Portugal d'agora (1911). After contextualizing Rio's interest in Portugal, I argue that the anecdote reveals a latent anxiety about the security of money as a reliable signifier, and about the integrity of the Portuguese monetary system. I contend that this anxiety constitutes one side - the obverse, in numismatic terms - of Rio's portrait of Portugal during the first years of the 20th century. The "reverse" consists of his descriptions of what we, following Sérgio Buarque de Holanda in Raízes do Brasil (1936), might term LusoBrazilian desleixo. In my conclusion, I connect Rio's two-sided view of Portugal with his later positions, as articulated in the journal Atlântida (1915-20), which he co-edited with João de Barros.
\end{abstract}

Keywords: Portugal d'agora, Charles Baudelaire, Sérgio Buaque de Holanda, Travel writing, Atlanticism

One of the many anecdotes recounted by the Brazilian writer Paulo Barreto (1881-1921), better known by his pen name, João do Rio, in the volume Portugal d'agora (1911), concerns the prevalence of counterfeit money in Portugal. ${ }^{1}$ Rio

\footnotetext{
${ }^{1}$ Barreto was sent to Portugal in 1908 by the Rio de Janeiro newspaper the Gazeta de Notícias. He would visit Portugal four times during his life. The Gazeta announced Barreto's presence in Portugal in its January 31, 1909 issue ("Paulo Barreto em Portugal"), and it began publishing his dispatches later that year. See Saraiva (83) for a literary assessment of Portugal d'Agora.
} 
introduces this apparently marginal element of his account of Portuguese customs, society, and literature, based on his inaugural 1908-09 visit to Portugal, in a tobacconist's shop in Porto. Here he attempts to spend one of the coroas ("grossas moedas de prata do valor de quinhentos réis. Enchem os bolsos, pesam nos bolsos") he received as change in Lisbon while purchasing a train ticket to Porto: "Na primeira tabacaria tiro uma das coroas. Escandalosamente falsa, mas de uma indecente falsidade. Parece um pedaço de chocolate em papel de prata" (93). Rio relates his experience in the tobacconist's shop to a group of Portuguese writers gathered in a Porto bookshop. His narrative prompts one of them, Manoel de Sousa Pinto (1880-1934), to share the following account of counterfeiting practice in Portugal:

Um cidadão resolveu falsificar, com certo engenho, vintens. Era tão perfeita a obra que pareceriam verdadeiros, se não tivessem um sinal de assignatura. Poz a estrella, inundou Portugal desse cobre, ganhou um dinheiro absurdo e, farto de ser tratante, retirouse definitivamente para o estrangeiro, mas com um rasgo de honestidade. Escreveu ao rei, contando o occorrido.

E, como eram muitos, os vintens ficaram na circulação. (Rio, Cartas 112)

The caso recounted by Sousa Pinto, framed by Rio's narration and his discovery of the counterfeit coin at the tobacconist's, recalls Charles Baudelaire's prosepoem "La fausse monnaie" (The counterfeit coin), included in his posthumous work Le spleen de Paris (Paris spleen, 1869). ${ }^{2}$ Putting aside the question of the veracity of Rio's anecdote, ${ }^{3}$ the fact that it bears a resemblance to Baudelaire's text is not particularly surprising. Like Baudelaire, Rio was a flâneur, and he shared the French poet's interests in the urban underworld, eroticism,

\footnotetext{
2 If we draw on Derrida's reading of "The Counterfeit Coin," we can place Rio's anecdote within a network of texts that includes Baudelaire, Poe's "The Purloined Letter" (1844), and Gide's Les Faux-monnayeurs (The counterfeiters, 1925). See Derrida (Given Time 84, 109-10). See also Derrida ("White Mythology" 210) on challenges to "the integrity of capital" and "the natural wealth and original virtue of the sensory image."

${ }^{3}$ Antelo (64-65) notes tensions between reportage and literature, and truth and fiction, in the crônica, Rio's preferred mode of expression.
} 
transgression, and moral relativism. ${ }^{4}$ And as was typical of the writers of the Brazilian belle époque, Rio was familiar with French literature, often cited French writers, and made passing mention of Baudelaire in Portugal d'agora (197).

Similarly, Rio's inclusion in his book of an anecdotal case of counterfeiting is consistent with his broader preoccupation-typical of fin-de-siècle literary culture - with liars, fraudsters and conmen, and by extension, with the subversion of established values and institutions. ${ }^{5}$ For example, in a section of A alma encantadora das ruas (1908) dedicated to Rio de Janeiro's "pequenas profissões," Rio describes the selistas who collect discarded cigar and cigarette box labels and cigar bands and sell them to unscrupulous tobacconists, who use them to pass off inferior products as prestige brands. In a tone that suggests both admiration and scandalized concern, he speculates on the dimensions of the selistas' racket: "Imagina uns cem selistas à cata de selos intactos das carteirinhas e dos charutos; avalia em 5\% os selos perfeitos de todos os maços de cigarros e de todos os charutos comprados neste país de fumantes; e calcula, após este pequeno trabalho de estatística, em quanto é defraudada a fazenda nacional diariamente só por uma das pequenas profissões ignoradas" (36).

Returning to the Rio-Baudelaire comparison, the two accounts bear certain structural similarities: both open with an individual examining coins at a tobacconist's shop; both feature conversation between the narrator and an acquaintance (in Baudelaire, an anonymous first-person narrator and a nameless "friend"); and both feature a specifically silver-colored counterfeit coin (in Baudelaire, a "silver two-franc coin"). ${ }^{6}$ More substantively, both narrators speculate about the implications of counterfeit currency entering circulation. In doing so, they reveal a latent anxiety—which as this comparison implies was

\footnotetext{
${ }^{4}$ Baudelaire's influence is also seen in the volume's final chapter, in which Rio discusses a bird that stows away on his ship during his return voyage to Brazil. The bird, removed from its habitat, refuses to eat and dies. This incident partially recalls Baudelaire's poem "L'albatros" (The albatross).

${ }^{5}$ In Brazil, this tendency intersects with, though it is not identical to, the literature of malandragem, as well as Machado de Assis's rich use of unreliable narrators. See, for example, Manuel Antônio de Almeida's Memórias de um sargento de milícias (1854-55), Machado’s Quincas Borba (1891) and Lima Barreto's "O homem que sabia javanês" (1911). See Candido and DaMatta for seminal interpretations of malandragem in Brazilian literature and culture.

6 "The tobacconist's is obviously the insignia or the sign of modernity" (Derrida, Given Time 102). It is also bears noting the "colonial" provenance of tobacco, and its function as a vehicle for transculturation, as a bonding agent between the New and Old Worlds. See Ortiz (181-253).
} 
operative at both the center (here Paris) and on the peripheries (Rio de Janeiro, Lisbon) of the global economic order at the fin de siècle-about the security of money as a reliable signifier, and the integrity of the monetary system, which depends on the public's belief that a silver coroa always equals 500 réis, for example. $^{7}$

This anxiety constitutes one side - the obverse, in numismatic terms - of Rio's portrait of Portugal during the first years of the twentieth century, an agitated period that witnessed the 1908 assassination of the Portuguese king and heir-apparent, and the October 5, 1910 revolution that overthrew the monarchy and installed the First Portuguese Republic (1910-26). ${ }^{8}$ The "reverse" side consists of Rio's descriptions of what we, following the Brazilian essayist and historian Sérgio Buarque de Holanda, might term desleixo, a quality Buarque would characterize a quarter century after Rio's Portugal d'agora, in Raízes do Brasil (1936), as a composite of down-to-earth realism, common sense, and personal tenacity that he viewed as emblematic of both Brazilian culture and its Portuguese "roots." In short, Rio depicts Portugal in contradictory, albeit deeply affectionate terms: as a country whose mismanaged institutions and corrupt political class would seem to render it ill-equipped for modernity but whose people possess an inherited temperamental vitality, a compensatory desleixo that might point the way forward for Portugal, and which Brazilians might hope to access as well. And as I describe in my conclusion, Rio's comments in Portugal d'agora also anticipate the "Atlanticist" positions he would adopt as co-editor, with Portuguese writer João de Barros, of the Luso-Brazilian journal Atlântida (1915-20) — these later positions being “Atlanticist" both for the journal's title and for their invocations of the Atlantic as a privileged avenue for Luso-Brazilian communication and exchange.

What is notable about Rio's writing on Portugal, beyond his biographical particularities, his impassioned local advocacy for Rio de Janeiro's Portuguese community, and his literary style, is his treatment of fin-de-siècle Portugal's encounter with modernity in terms of a not-yet resolved, perhaps irresolvable opposition between economic rationality, which he termed "a batalha sem fim do

\footnotetext{
7 See Marx and Nietzsche, quoted in Hoey (30-31), on the broader late-nineteenth-century preoccupation with money as a reliable signifier.

${ }^{8}$ From the preface to Portugal d'agora: "Portugal atravessa talvez a sua maior crise historica, crise que tinha e tem de ser definitiva para o seu futuro" (vii).
} 
mundo moderno, a batalha econômica" in a 1919 speech, and an inherited civilizational "genius" ("Portugal-Brasil" 448). This opposition is most clearly perceived in Rio's anecdote of the counterfeit coin. Before presenting the two sides of Rio's characterization of Portugal - "o verso e o reverso da medalha" as Miguel Torga might put it (205) — it may prove useful to describe what Rio termed his "curioso amor" for Portugal.

\section{Rio's “Curious Love” for Portugal}

Rio is best known for his crônicas of Rio de Janeiro street life, as a pioneering investigative reporter, and for courting scandal with his dandyism, polemical positions, and only lightly concealed homosexuality. ${ }^{9} \mathrm{He}$ was also one of fin-desiècle Brazil's most prominent Lusophiles, a group largely comprised of buttoned-up, politically connected, privileged writers of often unadventurous political and aesthetic inclinations (Joaquim Nabuco, Eduardo Prado, Olavo Bilac, etc.). Rio - the flamboyant mulatto chronicler of the carioca demimonde, a "tropical dandy," and professional journalist born to a middle-class familystands at some remove from this group (Trevisan 106; Martuscelli 77; Saraiva 125). Nonetheless, he was a great promoter of Portuguese literature and culture and an ardent defender of Rio's Portuguese community during a period of widespread lusofobia touched off by popular resentment against Portuguese immigrants and the nationalistic tenor of Brazilian politics at the time (Rio, Cartas 33; Martuscelli 74; Saraiva 72).

Rio made four transatlantic voyages, first visiting Portugal in 1908-09, while on assignment for the Gazeta de Notícias. These crossings led him to befriend young Portuguese writers who shared his interest in Luso-Brazilian approximation - including João de Barros, Carlos Malheiro Dias, and Manoel de Sousa Pinto ${ }^{10}$ — and to meet established voices like Fialho de Almeida and Guerra

\footnotetext{
${ }^{9}$ For Rio's dandyism, see: Antelo (78-79); Gomes (41); Trevisan (75-76, 106). Trevisan also makes the intriguing suggestion that Rio's style should be analyzed in terms of its proximity to camp (106).

${ }^{10}$ Barros (1881-1960), a poet, published several Luso-Brazilian-themed volumes, and visited Brazil on several occasions. His first, 1912 visit was coordinated by Rio. Dias (1875-1941), a journalist and historian, was the son of a Brazilian mother and Portuguese father, and as a monarchist lived in exile in Brazil for a time. Sousa Pinto (1880-1934) was born in Brazil and educated in Portugal. He published several volumes on Brazil. Dias and Sousa Pinto collaborated in Atlântida. Rio dedicated Portugal d'Agora to both men.
} 
Junqueiro, whom he lionized. He published two Portuguese-themed books, Portugal d'agora and Fados, canções e danças de Portugal (1909), and he arranged for some of his books to be published in Portugal by the prestigious Lello \& Irmão (Magalhães Júnior, 100-01). In 1915, he co-founded Atlântida (he co-edited it with Barros until 1920), which promoted, in richly illustrated and elaborately presented issues, a literary-intellectual, economic, and diplomatic approximation between Portugal and Brazil. It supported exchanges between the two countries, including Olavo Bilac's 1916 trip to Portugal, and it worked to construct a common Luso-Brazilian imaginary (Martuscelli 73). Rio viewed Portugal and Brazil as organically and fraternally linked, called for the two nations to defend the Portuguese language, and advocated for closer economic ties-positions he sketched out in Portugal d'agora. He expressed these views more forcefully in the context of Atlântida, a journal conceived, in Barros' words, as "um órgão de aproximação recíproca, em que se traduzam e expressem as energias, as ambições, os ideais dos dois povos" (75). ${ }^{11}$

Rio's lusofilia also led him to advocate for Rio de Janeiro's Portuguese community, an effort that drew on his experience as a reporter, editor, and polemicist. Despite its size and prominence in commerce, the press, fishing, and other sectors, Rio's Portuguese "colony" faced problems including poor labor conditions for working-class Portuguese immigrants and the previously noted upsurge in anti-immigrant sentiment, which became particularly acute during the presidency of Epitácio Pessoa (1919-22). As early as 1908, in A alma encantadora das ruas, Rio described the brutal conditions facing the primarily Portuguese workers who labored shoveling and loading manganese and coal on the industrial islands of Guanabara Bay. In March 1916, he mobilized the community to raise money for the Portuguese Red Cross, following Portugal's entrance into World War I (Rio, Cartas 237). And in 1920, he founded the newspaper A Pátria for the purpose of defending the poveiros, the members of Rio's fishing colony who hailed from Póvoa de Varzim, and whose livelihoods were threatened by a Brazilian government initiative to nationalize the industry,

\footnotetext{
${ }^{11}$ In Portugal d'agora, Rio describes Portugal and Brazil as "mais ligados do que quaesquer outros paizes, tendo o dever glorioso de manter viva uma lingua admiravel" (245), and he declares that its writers "têm a obrigação, o dever de conservar a grande obra das gerações, a lingua que é o espelho das raças" (253).
} 
and which began, in August 1920, to require all fishermen to be citizens (Rio, Cartas 53-61).

As Rio reveals in his correspondence, he suffered for his dogged support of Portugal and Portuguese immigrants. In a January 1916 letter to Barros, he notes the anger directed toward Atlântida by a "grupinho miserável" of anti-Portuguese Brazilian nationalists (Cartas 221). "Jacobin" journalists and commentators attacked him in the press, particularly during the fishing debate, with some insinuating that he had been paid off by Portuguese commercial interests, and others alluding maliciously to his sexuality (Rio, Cartas 58 and 60; Magalhães Júnior 368). In October 1920, a group of naval officers went so far as to physically attack him in a Rio de Janeiro restaurant for his support of the poveiros - an assault that led the Portuguese Senate to pass a resolution in support of him (Magalhães Júnior 363 and 367; Green 59). At least one biographer has speculated that the stress caused by these events may have contributed to Rio's sudden death by heart attack on June 23, 1921 (Magalhães Júnior 378).

In his correspondence with Barros, Rio quips, perhaps with some bitterness, that his services to "meu querido Portugalzinho" should merit a grant of citizenship and the naming of "várias ruas de Portugal" in his honor (Cartas 238, $346,350) .{ }^{12}$ In fact, he was honored by the Portuguese government and institutions, which were either unaware of or unconcerned with his homosexuality, which was an open secret in Brazil. In 1913, he was named a corresponding member of the Academia de Ciências de Lisboa, and in 1919, he received the Grã-Cruz of the Ordem Militar de Cristo and was named Comendador of the Ordem Militar de Sant'Iago da Espada. He was elevated to Grande-Oficial in the Ordem Militar do Cristo the following year.

Rio was vocal in his love for his "Portugalzinho," which he readily expressed in his published work and correspondence. In a 1909 letter to Malheiro Dias, written during his first trip to Europe, he wrote: "Eu vou [...] [da Europa] com grandes sentimentos que nunca tivera um dois quais é um curioso amor por

\footnotetext{
${ }^{12}$ Barros reported in 1943 that "[o] seu nome anda na boca da gente de Lisboa e da das províncias, embora - triste vergonha! — só uma 'Calçada' modesta, para os lados da Imprensa Nacional, o consagre perante a população da cidade, da cidade que celebrou em algumas páginas de harmoniosa beleza" (262).
} 
Portugal!" (372). In his 1909 introduction to his compendium Fados, canções e danças de Portugal, he declares:

Em Portugal, eu sou como um caso de delirio do atavismo, sou o patriota, que nunca aqui esteve. Amo o ceu, amo o campo, amo a hospitalidade intellectual, caio de joelhos deante do tumulo de Luiz de Camões, sympathiso com as pequenas do fado, gosto dos fadistas. Que fazer? Volto á primitividade da franqueza! (12)

And in his introduction to Portugal d'agora, he describes his book as a work "de um brasileiro que, certo do futuro da sua pátria, ama fervorosamente Portugal" $(\mathrm{xv}) .^{13}$

Rio was particularly struck, during his 1908-09 visit, by the physical beauty of the Portuguese - men and women alike - and he described this beauty in overtly sensual terms, a notable point of departure from the high-minded, official rhetoric generally employed by Luso-Brazilian men of letters during the period to promote closer transatlantic ties (Rio, Fados 2 and 4) ${ }^{14}$ In Fados, canções $e$ danças de Portugal, he remarks: "Artistas e esthetas graves já disseram que o homem de Portugal é o mais bello do mundo. E as mulheres, rapaz, quando não lembram Dante Gabriel Rossetti, lembram divinamente as figuras dos pintores do Renascimento. Tudo aqui é vida, é ardencia, é paixão" (3). ${ }^{15}$ And describing Lisbon's urban poor in Portugal d'agora, he reflects:

[T]oda aquella gente era bella, de uma belleza quente e sensual, que desabrochava nos labios polpudos, no meneio amplo dos quadris, naquelles olhos de extase, tão molhados, tão ingenuamente passionaes, que nos cantos das orbitas ainda se espraiava o brilho da pupilla ardente. E essa belleza sensual e

\footnotetext{
${ }^{13}$ For more on this, see Magalhães Júnior (99) and Vieira (134).

${ }^{14}$ Rio described Portugal, and particularly Lisbon, as spaces of seduction and sensuality.These descriptions are also notable for contradicting the well-worn stereotype of the Portuguese as physically unattractive, particularly in comparison to Brazilians.

${ }^{15}$ See also the following: "E era por toda parte essas caras quentes, esses olhos cheios de sonho e de luxuria, essas fisionomias boas e sorridentes, sorridentes e bellas dos portuguezes, eram os rostitos petulantes das lusitanas, tão lindas as de linha aristocratica como as do povo, de pés nús, côr de coral rosa por causa do frio, do narizito para o ar, dois olhos ardentes maravilhadas da vida." See Rio (Fados 1-2).
} 
natural, recordando kerméses delirantes, tinha em cada face uma infinita expressão de poesia e de bondade. $(38-39)^{16}$

Here the word bondade (goodness) is significant, for in addition to describing the Portuguese as physically beautiful, Rio repeatedly characterized them as a fundamentally good, decent people, and described Portugal as a "pequeno paiz de bondade e belleza" (283). ${ }^{17}$ The goodness Rio ascribed to the Portuguese, particularly to the common people, was closely connected to what he understood as their capacity for dignified "resistance" in the face of life's difficulties. For instance, he celebrates Portugal's rural population as "[soffrendo] tudo com infinita e admiravel capacidade de resistencia" (208), an idea he may have borrowed from José Barbosa's As relações luso-brasileiras (1909), a text he cites in Portugal d'agora. ${ }^{18}$ This resistant, tenacious quality, an aspect of what Buarque would later term Luso-Brazilian desleixo, acts in Rio's account to counterbalance the pessimistic implications of his anecdote of the false coin. Let us now examine these implications, returning to the Rio-Baudelaire comparison proposed at the outset of this paper.

\section{Obverse: "Scandalously, indecently false"}

In "The Counterfeit Coin,” Baudelaire's narrator, prompted by his realization that his friend has knowingly given a beggar a counterfeit two-franc coin, considers:

[...] the various consequences, harmful or not, that a false coin in a beggar's hands might produce. Might it not multiply into real coins? Might it not also lead him to prison? A tavern keeper, a baker, for example, might have him arrested as a counterfeiter or a propagator of counterfeit coins. Or the false coin could just as

\footnotetext{
${ }^{16}$ See also Rio's description of the washerwomen of Matosinhos and their male lovers, whom he describes as "Daphnes" and "young Bacchuses," respectively (Portugal 261).

${ }^{17}$ See also Rio, Portugal 202; Fados 31 and 36).

${ }^{18}$ Barbosa writes, in a line quoted by Rio: "Nenhuma raça revéla maior resistencia do que a nossa, nenhuma é mais soffredora e tenaz" (Barbosa 6; Rio, Portugal 294). See also Rio (Portugal 118 and 135).
} 
well become, for a poor little speculator, the seed of a few days' wealth. (69-70)

Baudelaire's narrator speculates on the potential consequences of the counterfeit coin for the beggar who now possesses it, whom he imagines may be arrested or conversely, might illegally profit by "multiply[ing]" the counterfeit coin "into real coins." 19 Jacques Derrida argues, in his well-known reading of Baudelaire's fragment, that the author-narrator's speculations take a philosophical turn:

He speculates on what can happen to capital in a capital during the age of money, more precisely, in the age of value as monetary sign: The circulation of the counterfeit money can engender, even for a 'little speculator,' the real interest of a true wealth. Counterfeit money can become true capital. Is not the truth of capital, then, inasmuch as it produces interest without labor, by working all by itself as we say, counterfeit money? Is there a real difference here between real and counterfeit money once there is capital? (Given Time 124)

For Derrida, then, Baudelaire's fragment "interrogates obliquely" the purported solidity of money, and of the monetary system (110n.1).

Rio's anecdote, when considered in light of Portugal d'agora as a whole and the author's broader, typically fin-de-siècle interest in frauds and cons, likewise reveals doubts regarding money and questions the integrity of the Portuguese monetary system-much in line with the spirit of Derrida's reading of Baudelaire. Further, Rio also questions the solidity of the Portuguese ancien régime, which he describes elsewhere in the volume as wracked by mismanagement and paralysis. Though here the narrator's anxiety is directed not against the consequences of the state's enforcement of monetary norms, as in Baudelaire, but rather against the fragility of the Portuguese system, as revealed in its inability to enforce these norms, or its lack of interest in doing so. This anxiety is counterbalanced in Rio's account of desleixo and his claim that this is a typifying feature of Luso-Brazilian civilization.

\footnotetext{
${ }^{19}$ Though he does not necessarily show sympathy for the beggar. See Scott (111).
} 
Rio describes fin-de-siècle Portugal, months away from the inauguration of the Republic, as a country beset by political crisis and economic polarization between an underdeveloped countryside and a decadent capital. He charges successive governments with having mismanaged the economy, leading to mass emigration - to Brazil, particularly — and to underinvestment in agriculture and industry: "Portugal é um paiz forte a que phenomenos economicos da ha longos annos e mesmo seculos vem trazendo a depauperante emigração, individualmente rendosa, mas para a patria desastrosa" (71). At the same time, the sophistication of Lisbon, which he considers to be a modern city dominated by the cult of appearances ("Lisboa [...] é civilisada e demonstra a sua civilisação pelo perpetuo esforço de apparentar. Apparentar é tudo na vida. A apparencia é a legenda, a apparencia é necessaria à existencia como o sol ás plantas" (78)), masks the rot on display in the countryside. Rio finds Lisbon's veneer of civilization appealing if unsustainable and psychologically damaging. ${ }^{20} \mathrm{He}$ remarks that Lisbon is expensive for him as a Brazilian visitor, ${ }^{21}$ and more so for the Portuguese middle class whose salaries are insufficient to cover the costs of "civilized" life, though who are nonetheless compelled to "keep up appearances" by dressing well, attending the theater, and so on. Presiding over this landscape of rural deprivation and decadent urban chic are Portugal's politicians, whom he accuses of having forgotten "a base rural de Portugal e [criado] uma burocracia numerosa e inutil" (226).

In this light, the decision in the anecdote to keep the counterfeit vinténs in circulation, whether made by the king or his ministers, is troubling. ${ }^{22}$ Unlike

\footnotetext{
20 "Lisboa tem da civilisação das grandes cidades a correcção de facto e a correcção do cumprimento. Nada de excessos, nada de gritos. Essa gente parece que toda ella frequenta o paço das Necessidades" (Portugal 91). For Rio's views on the cult of appearances and modernity, see "O figurino" from Psicologia Urbana (1911): "Estamos na era da exasperante ilusão, do artificialismo, do papel pintado, das casas pintadas, das almas pintadas" (90). See also the following: "Todos nós, os civilisados, os superiores - essa grande pilheria intellectual do superhomem - que vivemos uma vida artificial de convenção, julgando hypocritamente o mal pelo bem quando nos convem e o bem pelo mal para satisfazer os sordidos instinctos do egoismo, acabamos por ter uma alma dupla" (Fados 43).

21 "Logo á chegada, desde que as libras se transformaram em dinheiro forte, fiquei com a idéa de que era um sujeito fortissimamente forte. Mas era engano. O dinheiro forte corria não como a libra e o franco, mas como o nosso fraco papel" (Portugal 166). See also Magalhães Júnior (98).

22 The use of the passive voice ("como eram muitos, os vintens ficaram na circulação") makes it impossible to determine who decided to keep the coins in circulation, assuming the anecdote is grounded in reality. Silver 500-réis coins were minted throughout the nineteenth century in Portugal and through the reign of D. Manuel II (1908-10).
} 
Baudelaire's fragment, in which the beggar in possession of the counterfeit coin risks punishment by the State, Rio's account presents the Portuguese state (here personified by the king) as unable or unwilling to defend the integrity of the monetary system. He determines that the state-along with the public, presumably - will pretend that the counterfeiting never happened, and that the false vinténs, despite their telltale star, are real. Derrida observes the destabilizing impact of such an acquiescence in his extended meditation on Baudelaire:

Counterfeit money is never, as such, counterfeit money. As soon as it is what it is, recognized as such, it ceases to act as and to be worth counterfeit money. It only is by being able to be, perhaps, what it is. This irreducible modality taken into account [...] obligates you. It obligates you first of all to wonder what money is: true money, false money, the falsely true and the truly false [or "scandalously false," for Rio] - and non-money which is neither true nor false, and so forth. (Given Time 87)

In short: if the Portuguese state abrogates its responsibility to define and defend the legal value of money by ceasing to enforce the distinction between "real" and "false" currency, the notion that any object, whether a coin or paper, can represent a stable, consistent, and commonly accepted store of value and medium of exchange will collapse ${ }^{23}$ and the arbitrariness of the currency-as-sign will be exposed. ${ }^{24}$ Moreover, the State's failure to defend the integrity of the monetary system will presumably contribute to a collective loss of faith in government, or more gloomily, may indicate that this collective faith has already been eroded or lost altogether.

This reasoning leads us to a pessimistic interpretation of Rio's anecdote, in which the Portuguese leadership, and perhaps Portugal as a whole, appears illequipped for the modern world. But Rio counterbalances this pessimistic assessment with an abiding faith in the Portuguese people, whose underlying

\footnotetext{
${ }^{23}$ See Martins, who argues against the printing of non-convertible paper money, comparing this practice to "as antigas falsificações da moeda metalica" (Circulação 18).

${ }^{24}$ Rio writes in "O figurino," from Psicologia Urbana: "O que são os princípios em política, em economia, em estética? [...] O livre cambismo em economia é ou não um figurino renovado como o penteado à grega? (92-93).
} 
qualities would seem to offer Portugal a way out of the morass. Rio describes his position as follows, with recourse to the first-person observation he depends upon throughout the volume:

Duas ou tres semanas depois de estar em Portugal tem-se a impressão de que o unico mal de Portugal, mal de bilitante [sic], mal terrivel - é a politica, ou antes, desde que nada se commenta ou resolve numa calma e sã atmosphera - a politicagem, politicagem envenenadora, que estabelece um circulo vicioso meio rabido, cujo fim é fatalmente estalar. Ha situações que não podem durar eternamente: ou o paiz acaba com ellas ou ellas com o paiz, e, dada a prodigiosa e legendaria força de resistencia de Portugal, é a nação que acabará por desfazel-as. (204-05)

I explore this notion of resistance in greater detail in this paper's next section, as a component of Buarque's notion of Luso-Brazilian desleixo.

\section{Reverse: A “Plain and Rough Realism”}

In the fourth chapter of his classic Raízes do Brasil (1936), Buarque introduces the term desleixo, which immediately suggests laxity, but which he argues reflects a particular combination of resignation, pragmatism, and resistance, a "chão e tosco realismo" bequeathed from the Portuguese to the Brazilian people and manifested in Portugal's gradualist approach to overseas navigation and expansion (110; Martins, História 1, 48). ${ }^{25}$ Buarque defines desleixo as follows:

A cidade que os portugueses construíram na América não é produto mental, não chega a contradizer o quadro da natureza, e sua silhueta se enlaça na linha da paisagem. Nenhum rigor, nenhum método, nenhuma previdência, sempre esse significativo abandonado que exprime a palavra 'desleixo' - palavra que o escritor Aubrey Bell considerou tão tipicamente portuguesa como

\footnotetext{
${ }^{25}$ See also Freyre's reference to the "espírito político e de realismo econômico e jurídico que aqui, como em Portugal, foi desde o primeiro século elemento decisivo de formação nacional" (6).
} 
'saudade' e que, no seu entender, implica menos falta de energia do que uma íntima conviç̧ão de que 'não vale a pena...'Pode-se acrescentar que tal conviç̧ão, longe de exprimir desapego ou desprezo por esta vida, se prende antes a um realismo fundamental, que renuncia a transfigurar a realidade por meio de imaginações delirantes ou códigos de postura e regras formais (salvo nos casos onde estas regras já se tenham estereotipado em convenções e dispensem, assim, qualquer esforço ou artifício). Que aceita a vida, em suma, como a vida é, sem cerimônias, sem ilusões, sem impaciências, sem malícia e, muitas vezes, sem alegria. $(110)^{26}$

From the perspective of the integrity of the Portuguese monetary system - and of currency-as-sign, as Derrida alerts - the decision to leave the counterfeit vinténs in circulation is alarming, and seems to reflect an inertia, lack of concern for governance, or ignorance of basic economic principles that would point to the inevitable fall of the monarchy, as in fact occurred in October 1910. And yet, when approached from the standpoint of desleixo, the king's (or his government's) decision may be seen as reflecting a Portuguese "fundamental realism" and acceptance of "life as it is"-which like Buarque, Rio presented as traits common to Portuguese and Brazilians. Strict adherence to "codes of regulations and formal rules" would dictate that the counterfeiter be punished in absentia, even though he is beyond the reach of the law, and that his counterfeit coins be accounted for, though they are numerous ("eram muitos") and have already entered into circulation. Given these facts, rigid enforcement of monetary norms ex post facto would seem impractical and difficult, if not impossible. Is this refusal to try to undo a past transgression in the name of abstract norms, far from an invitation to generalized "disorder," ${ }^{, 7}$ not an example of the "plain and rough realism" identified by Buarque as a defining Luso-Brazilian characteristic?

\footnotetext{
26 Santiago draws out the importance in Raízes do Brasil of desleixo, a term somewhat overshadowed by Buarque's better-known figures of the semeador and ladrilhador and homem cordial, along with his notions of competing ethics of trabalho and aventura. See Santiago (97-98, 228, 241-49).

${ }^{27}$ See Santiago (228) on desleixo versus disorder.
} 
Supporting this interpretation are references by Rio in his book's preface, written after the establishment of the Republic, to the actions of the Portuguese people immediately following the fall of the monarchy. ${ }^{28}$ He writes that upon arriving in Lisbon for the second time, just after the monarchy's fall, he received the "notícia horrivel" that the entire country was on strike. To his relief, he discovered that these were strikes à portuguesa:

Os telegrammas dos jornaes estrangeiros anunciavam as grèves como um feroz final da republica. O mundo pensaria que Portugal fazia grèves como os outros paizes. Não! Cem vezes não! Portugal fez grèves lyricamente, para entrar na corrente contemporanea, como quem dá um amplexo de cordialidade mundial, para mostrar a sua capacidade nesse terreno de protesto socialista. (ix-x)

Rio suggests that the lack of violence witnessed during the strikes is attributable to his view of the Portuguese character, which as I have argued can be described by the term desleixo, here characterized as a combination of bom senso and sentimental patriotism of the sort that that would preclude violent extremismor in the context of the anecdote of the counterfeit coin, a too-rigorous enforcement of the law: "Assim, sem mortes, sem crimes, sem grandes estragos, Portugal, dias depois da Republica dava a amostra do seu adeantamento socialista. Mas nem por isso, o portuguez, mesmo com a violenta transformação, perdia as suas qualidades fundamentaes de bom senso e de amor ao paiz" (xi). In noting that the Portuguese protested peacefully and avoided revolutionary excesses, Rio gestures toward a desirable future for the young Portuguese Republic, one in which the demands of modernity would be reconciled to its people's fundamental qualities, which he posits are shared by the Portuguese and their Brazilian "children." We can view the perhaps pragmatic, perhaps resigned

28 While Rio favored a republic for Portugal, he described the Portuguese monarchy as "democratic," and humanized certain members of the royal family. For instance, he writes of D. Manuel II in seductive terms, similar to those he used to describe the Portuguese people, and observes that "[a] monarchia portugueza é essencialmente democratica" (the Portuguese monarchy is essentially democratic) while describing the king's uncle, D. Afonso, driving his car around Lisbon. See Rio (Portugal 85, 201). 
action of the king in the anecdote in this light, as reflecting an underlying quality or set of qualities, which Buarque would collectively term desleixo, that to Rio's thinking will stand the Portuguese in good stead as they attempt to build a new, republican society. Rio presents this view in more sustained form in the context of Atlântida, and in particular in his address, "Portugal-Brasil após a guerra," which he delivered in Lisbon at the Teatro Nacional on June 7, 1919, and which was published in the fortieth issue of the journal. I turn now to this speech as a means to move Rio's view of Portugal into the late 1910s and toward "Atlanticism" and its discursive inheritors during the mid-twentieth century.

\section{Conclusion: The Dream of Atlantis}

Rio's "Portugal-Brasil após a guerra" makes for interesting reading when considered alongside the earlier Portugal d'agora. On the one hand, his 1919 speech advocates for several positions first presented in his 1911 book (a common Luso-Brazilian defense of the Portuguese language, closer trade ties, etc.), though stylistically, it largely abandons the first-person observation, colorful anecdotes, and vivid expressions of emotion that typify Portugal d'agora and the introduction to Fados, canções e danças de Portugal. In his speech, Rio employs a high-flown, fraternal rhetoric typified by Olavo Bilac, who in his March 30, 1916 speech in Lisbon, "Aos Homens de Letras de Portugal" referred to "Portugal e o Brasil, as duas patrias eternamente irmãs" (156), and by Guerra Junqueiro, in his April 3, 1916 speech "Portugal-Brasil," delivered in honor of Bilac's visit. ${ }^{29}$ Rio, referring to the just-concluded First World War, in which Portugal participated on the side of the allies, acknowledges the continued challenge of modernity: "[C]ada país tem diante de si uma batalha muito mais feroz, muito mais terrível - a batalha sem fim do mundo moderno, a batalha económica" (448). And he refers to the errors of past Portuguese governments, which "abandonaram a pouco e pouco êsse povo. Apenas, sem o auxílio dos governos, o povo continuou o mesmo, cada um seguindo a aventura, sulcando os mares com o sonho da Humanidade" (452).

\footnotetext{
${ }^{29}$ See also Malheiro Dias, who declared in a 1919 speech in Lisbon in honor of Rio's latest visit: "[As bandeiras dos dois países] prosseguirão, lado a lado, cada uma palpitando em sua haste, como duas irmãs, o seu caminho através dos tempos e da história" (quoted in Martuscelli, 79).
} 
Rio suggests the "idea espléndida" of mutual approximation between Portugal and Brazil as a means to meet these challenges, though his language is significantly more forceful than in Portugal d'agora, and here he favors broad observations over anecdote (440). Rejecting as strictly unscientific the idea of biological race, Rio nonetheless affirms "race" as a category bound up with Romantic notions of a collective national or civilizational "genius," and joins together Portuguese and Brazilians as members of a single "race." It follows that Portuguese and Brazilians alike possess the qualities of "resistência física," "coragem," and "entusiasmo de Aventura." He goes as far as to state that "o Brasil, hoje é-rendamos graças à nossa prestigiosa raça!-português nos hábitos, nos usos, no fervor idealístico," and he describes himself, whether biologically or spiritually, as "filho dêsses conquistadores." ${ }^{30}$ Hence, Rio declares himself obliged to "considerar patriotismo português amar o Brasil e patriotismo brasileiro amar Portugal” (Portugal d'agora 449).

Rio's rhetoric in "Portugal-Brasil após a guerra" also contains a pronounced "Atlantic" or "Atlanticist" dimension. This reflects "o sonho da Atlântida" as announced in the inaugural November 15, 1915 issue of Atlântida, ${ }^{31}$ and echoed by Guerra Junqueiro, whom Rio greatly admired, in his April 3, 1916 speech "Brasil-Portugal," delivered in Lisbon in honor of the visiting Bilac. Here Junqueiro declares:

As nossas patrias desligaram-se, para melhor se casarem. Desuniram os corpos, para estreitarem as almas. Duplicando-se, quizeram-se mais. $\mathrm{O}$ amor cresceu em beleza porque aumentou em liberdade. Vivendo tão livres e distantes, fraternisamos hoje como nunca. Na gloria e no sonho, nos ais e nos beijos, no riso e na dor. Amando-nos através das ondas, vencemos o espaço. (110)

\footnotetext{
${ }^{30}$ See also: "E nós outros, brasileiros, filhos da mesma raça, falando a mesma língua, continuando a mesma arte, com os mesmos sentimentos de triunfo e resistência - nós somos o grande Portugal do outro lado [do Atlântico]." See Rio ("Portugal-Brasil" 457)

${ }^{31}$ See from Rio's "O sonho da Atlântida": "O Atlântico é [...] um resultante do espirito mediterraneo; é a obra da tenacidade idealistica e pratica dos humanos. Fomos nós que o criamos para a vida, porque fomos nós que o disvirginámos. Elle é nosso, porque aos poucos fomos a descobril-o, a povoal-o, a dominal-o" (13).
} 
Rio follows Junqueiro in his speech in alluding to Luso-Brazilian affection "across the waves," though his call is coupled with a militancy and imperial nostalgia that point, perhaps unexpectedly, toward the transatlantic imaginary promoted by the dictatorial Portuguese and Brazilian Estado Novo governments during the 1940s and 1950s. Looking to the future, Rio conjures into being the image of a Luso-Brazilian mare nostrum, later described in literary terms by Fernando Pessoa in his poem "Mar Português" from Mensagem (1934), and given a more much strictly politicized, reactionary form in the transatlantic journal Atlântico (1942-50), which was edited by the Portuguese modernist poetturned-propagandist António Ferro and co-sponsored by both governments. Rio writes:

E é este o momento do diamante, em que a nossa Raça vai trabalhar em Portugal para fazê-lo magnífico; é êste o momento em que a nossa Raça trabalha no Brasil para torná lo [sic] formidável; é êste o momento solar em que, olhando-nos por sôbre o mar da esperança universal, o Atlântico-nós nos devemos sentir com a força de fazê-lo o nosso caminho, a nossa estrada, o ligador do império do labor activo luso-brasileiro - o nosso mar. $(451){ }^{32}$

Rio's effusive love of Portugal and the Portuguese remains intact in his 1919 speech: "Quando pela primeira vez vindo a Portugal vos encontrava no agudo período da revolução republicana, vós outros destes-me o exaltador prazer de ter compreendido em mim o coração sinceramente amigo" (440). However, a good amount of the humanity and nuance contained in his portrait of the country and its people in Portugal d'agora - and revealed in the anecdote of the counterfeit coin - has been eliminated in favor of civilizational confidence and a composite, "Atlanticist" Luso-Brazilian nationalism. This late rhetorical shift, while perhaps surprising, is worthy of a writer whose career was built on controversy and contradiction, but who was remarkably consistent in his lusofilia and defense of

\footnotetext{
${ }^{32}$ Ferro specifically referred to the Atlantic as a Luso-Brazilian mare nostrum. See Martuscelli (146).
} 
Luso-Brazilian approximation, regardless of the political climate and personal costs.

\section{Works Cited}

Antelo, Raúl. Rio. O dândi e a especulação. Taurus-Timbre, 1989.

Barbosa, José. As relações luso-brasileiras (A immigração e a ‘desnacionalização’ do Brasil). Commercio, 1909.

Barros, João de. Presença do Brasil: páginas escolhidas (1912-1946). Dois Mundos, 1946.

Baudelaire, Charles. "The Counterfeit Coin.” The Parisian Prowler. Le spleen de Paris, petit poèmes en prose, translated by Edward K. Kaplan, U of Georgia P, 1997, pp. 69-70.

Bilac, Olavo. Ultimas conferencias e discursos. Alves, 1924.

Buarque de Holanda, Sérgio. Raízes do Brasil, Companhia das Letras, 2009.

Candido, Antonio. "Dialectic of Malandroism." On Literature and Society, translated and edited by Howard S. Becker, Princeton UP, 1995, pp. 79103.

DaMatta, Roberto. Carnivals, Rogues, and Heroes: An Interpretation of the Brazilian Dilemma, translated by John Drury, U of Notre Dame P, 1991.

Derrida, Jacques. Given Time: I. Counterfeit Money, translated by Peggy Kamuf, U of Chicago P, 1992.

—. "White Mythology." Margins of Philosophy, translated by Alan Bass, U of Chicago P, 1982, pp. 207-71.

Freyre, Gilberto. Casa-Grande \& senzala: formação da família brasileira sob o regime de economia patriarcal, Volume 1, José Olympio, 1961.

Gomes, Renato Cordeiro. Rio: vielas do vício, ruas da graça. Relume-Dumará, 1996.

Green, James N. Beyond Carnival: Male Homosexuality in Twentieth-Century Brazil. U of Chicago P, 1999.

Hoey, Allen. "The Name on the Coin: Metaphor, Metonymy, and Money."

Diacritics, vol. 18, no. 2, 1988, pp. 26-37.

Junqueiro, Guerra. Prosas dispersas. Lélo \& Irmão, 1921.

Magalhães Júnior, Raimundo. A vida vertiginosa de João do Rio. Civilização Brasileira/Instituto Nacional do Livro, 1978. 
Martuscelli, Tania. (Des)Conexões entre Portugal e o Brasil: séculos XIX e XX. Colibri, 2016.

Oliveira Martins, J.P. de. A circulação fiduciaria: memoria apresentada á Academia Real das Sciencias de Lisboa. Pereira, 1899.

—. Historia de Portugal. Pereira, 1901.

Ortiz, Fernando. Cuban Counterpoint: Tobacco and Sugar, translated by Harriet de Onís, Duke UP, 1995.

Rio, João do. A alma encantadora das ruas. Estado do Rio de Janeiro, 2007.

-. Cartas de Rio: a João de Barros e Carlos Malheiro Dias, edited by Cristiane d'Avila, Fundação Nacional de Artes, 2012.

—. Fados, canções e dansas de Portugal. Garnier, 1909.

—. Portugal d'agora. Garnier, 1911.

—. "Portugal-Brasil após a guerra." Atlântida, vol. 4, No. 40, 1919, pp. 440-59.

—. Psicologia urbana. Ministério da Cultura/Fundação Biblioteca Nacional, 2015.

—. "O sonho da Atlântida." Atlântida, vol. 1, no. 1, 1915, pp. 10-15.

Santiago, Silviano. As raízes e o labirinto da América Latina. Rocca, 2006.

Saraiva, Arnaldo. Modernismo brasileiro e modernismo português: subsídios para o seu estudo e para a história das suas relações. Unicamp, 2004.

Scott, Maria C. Baudelaire's Le Spleen de Paris: Shifting Perspectives. Ashgate, 2005.

Torga, Miguel. Antologia poética. Dom Quixote, 2001.

Trevisan, João S. Perverts in Paradise, translated by Martin Foreman, Global Media Publishing, 1986.

Vieira, Nelson H. Brasil e Portugal: a imagem recíproca (o mito e a realidade na expressão literária). Ministério da Educação/Instituto de Cultura e Língua Portuguesa, 1991. 